\title{
AN ANALYSIS OF MISSISSIPI (U.S.A.) HONEY : POLLEN, COLOR AND MOISTURE
}

\author{
Meredith Hoag LIEUX \\ Department of Botany, Louisiana State University, Baton Rouge, Louisiana 70803
}

\begin{abstract}
SUMMARY
A honey analysis technique utilizing acetolysis was applied to 68 commercial Mississippi (U.S.A.) honey samples collected in 1977 and 1978 . Total pollen grains per 10-g sample, pollen spectrum, color and moisture content of the honeys were determined. A majority $(67.6 \%)$ of the honeys had less than 20,000 grains per sample. Of the 84 pollen types identified, 65 were from nectariferous plants. A direct correlation was assumed between a plant's pollen and nectar contributions to a honey. On this basis, the major Mississippi honey plants in order of decreasing significance were Salix spp., Berchemia scandens, Glycine max, Rubus spp., Rhus toxicodendron and Trifolium repens. Based on frequency of occurrence (i.e., the number of honey samples in which a type occurred), the leading species in order of decreasing significance were Rubus spp., Salix spp., R. toxicodendron, T. repens and B. scandens. Salix spp., G. max and $B$. scandens produced the greatest number of unifloral samples. Important nectar contributors in isolated samples were Trifolium incarnatum, Parthenocissus quinquefolia, long-spined Compositae (Asteraceae), Rhus copallina, Vicia spp., Ilex spp., Zanthoxylum clava-herculis and Cyrillaceae (Cliftonia monophylla and Cyrilla racemiflora). Of the samples, $52.9 \%$ were of unifloral origin; the remainder were mixed floral honeys; $61.7 \%$ contained 16 to 25 pollen types. Most samples were summer-(G. max or spring-produced. Honeys from the different beekeeping areas were not clearly distinguishable by pollen analysis.
\end{abstract}

Key words : Acetolysis, beekeeping, honey, honeybees, nectar, pollen.

\section{INTRODUCTION}

Few papers have been published on the microscopic analysis of North American honeys or related aspects. Young (1908) described pollen grains from flowers commonly visited by bees. He also described, photographed and developed a key to pollen grains from American honeys and recorded various other structures, e.g., insect appendages, fungal spores, honeycomb fragments. PARKER (1923) presented 
descriptions of 28 types and 12 photographs of bee pollen grains collected in the United States. Hoffman (1930) published descriptions and illustrations of American honey pollen grains and developed a key for 28 types. ToDD and VANSELL (1942) studied pollen grains in nectars and honeys from California plants. Youse (1953) presented descriptions, a key and some photographs for 60 pollen grains collected by honeybees in Indiana. In the United States, methods for microscopic analysis of honey were discussed by Brown (1960). Louveaux (1966) applied the classic methods of MaURizio and Louveaux (1963) to microscopic analysis of 40 samples of Canadian honey. Using the same methods, VoRwoHL (1970) characterized the microscopic spectrum of 11 samples of Florida honey and included photographs of the most important pollen types. LiEUX $(1972,1975,1977,1978)$ characterized the pollen spectrum of 54 commercial Louisiana honeys and described dominant, secondary, and minor pollen types and their associated plants. Feller-Demalsy and Lamontagne (1979) established a pollen spectrum for 206 honey samples from all of the beekeeping areas of Quebec, Canada.

A honey analysis technique utilizing acetolysis (LIEUx, 1980) was applied in this study of 68 honey samples from Mississippi to determine botanical origin, geographical origin and season of production.

\section{MATERIALS AND METHODS}

Collection and preparation of reference pollen

A list of potential Mississippi honey and/or pollen plants was obtained from OerTel (1939). Lieux's pollen collection (Department of Botany, Louisiana State University, Baton Rouge) was used as the primary reference. Additional reference slides were prepared as needed from pollen collected from herbarium specimens and acetolyzed according to ERDTMAN (1952).

\section{Collection and preparation of honey samples}

Lists of commercial beekeepers in Mississippi were obtained from the Mississippi State Entomologist. Beekeepers were contacted by mail and requested to collect uncontaminated (not mixed with samples from other locations) commercial honey samples from their apiaries during the spring, summer and fall of 1977 and 1978. Self-addressed stamped mailing tubes containing jars were provided for return of the honey samples. The samples were acetolyzed and Millipore-filtered (LIEUX, 1980). Filter papers with the remaining honey sediment were transferred to slides.

\section{Microscopic examination of honey sediment and data presentation}

Each slide containing honey sediment from potential nectar-producing species was examined under high power $(400 \mathrm{X})$ by traversing the slide until 300 pollen grains were counted. The grains were identified to the lowest taxon possible. Unknown and unidentifiable entomophilous-appearing grains were included in the 300-grain counts. Separate counts were made for pollen grains of anemophilous or nectarless plants. When numerous grains rendered counting difficult, an eyepiece net micrometer $(10 \times 10 \mathrm{~mm}$, divided into $2 \mathrm{~mm}$ squares) was used. Frequency classes of pollen grains were designated according to Louveaux et al. (1978): " predominant pollen," greater than $45 \%$ of the pollen grains 
counted; "secondary pollen," 16-45\%; "important minor pollen," 3-15\% and "minor pollen," less than $3 \%$. The presence of a predominant pollen indicated a " unifloral honey," i.e., a honey produced mainly from a single plant species. A honey with no predominant pollen and few honeydew indicators was considered mixed floral. A direct correlation was assumed between a plant's pollen and nectar contributions to a honey.

The total number of pollen grains per 10-g sample was approximated according to LouvEAux's formula (Louveaux et al., 1978). A discriminant analysis was used to determine if group homogeneity warranted an analysis of variance to show a relationship between total number of pollen grains in a $10-\mathrm{g}$ sample of a honey and its floral type.

BRowN's [1970?] vegetational areas defined the beekeeping areas (Fig. 1) for this study; sample sites are indicated in Figure 2. Frequency of occurrence of a pollen type was based on the number of honey samples in which a type occurred. Most scientific and common botanical names used are from CORRELL and JoHNSTON (1970).

\section{Color and moisture determination of raw honey}

The color of each honey sample was determined with a simple color grader (Phoenix Precision Instrument Co., $3803 \mathrm{~N}$. 5th St., Philadelphia, Pa.) of the type described by Sechrist (1925: 7). Standard colors, in order of increasing intensity, were water white, extra white, white, extra light amber, light amber and amber. The moisture content of each honey sample was determined with a Bausch and Lomb Hand Refractometer (Cat. Nos. 33-45-31).

A discriminant analysis was used to determine if group homogeneity warranted an analysis of variance to show a relationship between honey color and floral type and between moisture content and floral type.

\section{RESULTS}

In Mississippi, $67.6 \%$ of the 68 honey samples had less than 20,000 grains per 10 g sample; $25.0 \%, 20,000-100,000 ; 7.4 \%, 100,000-500,000$. Counts for only unifloral honey samples are placed in Table 1 . Respectively, $36 \%, 90 \%$ and $71 \%$ of Salix spp. (willow), Glycine max (L.) Merr. (soybean) and Berchemia scandens (Hill) $\mathrm{K}$. Koch (rattan vine) samples showed less than 20,000 pollen grains in $10 \mathrm{~g}$ of honey.

A discriminant analysis showed that intergroup variation negated the use of an analysis of variance to compare total number of pollen grains and color or moisture of honey to floral type.

Eighty-four pollen types were identified in the honey samples (Fig. 3) : 65 were from nectariferous plants; 11 , polliniferous plants; 8, non-honeybee-associated plants. Table 2 gives a complete pollen spectrum of the 65 nectariferous species. Predominant and secondary pollen types are recorded in Table 3 in order of decreasing frequency of occurrence. The most important nectariferous plant contributors for Mississippi honey (based on total number of pollen grains) in order of decreasing significance were Salix spp., Berchemia scandens, Glycine max, Rubus spp. (blackberry and dewberry), Rhus toxicodendron L. (poison ivy) and Trifolium repens L. (white clover). 


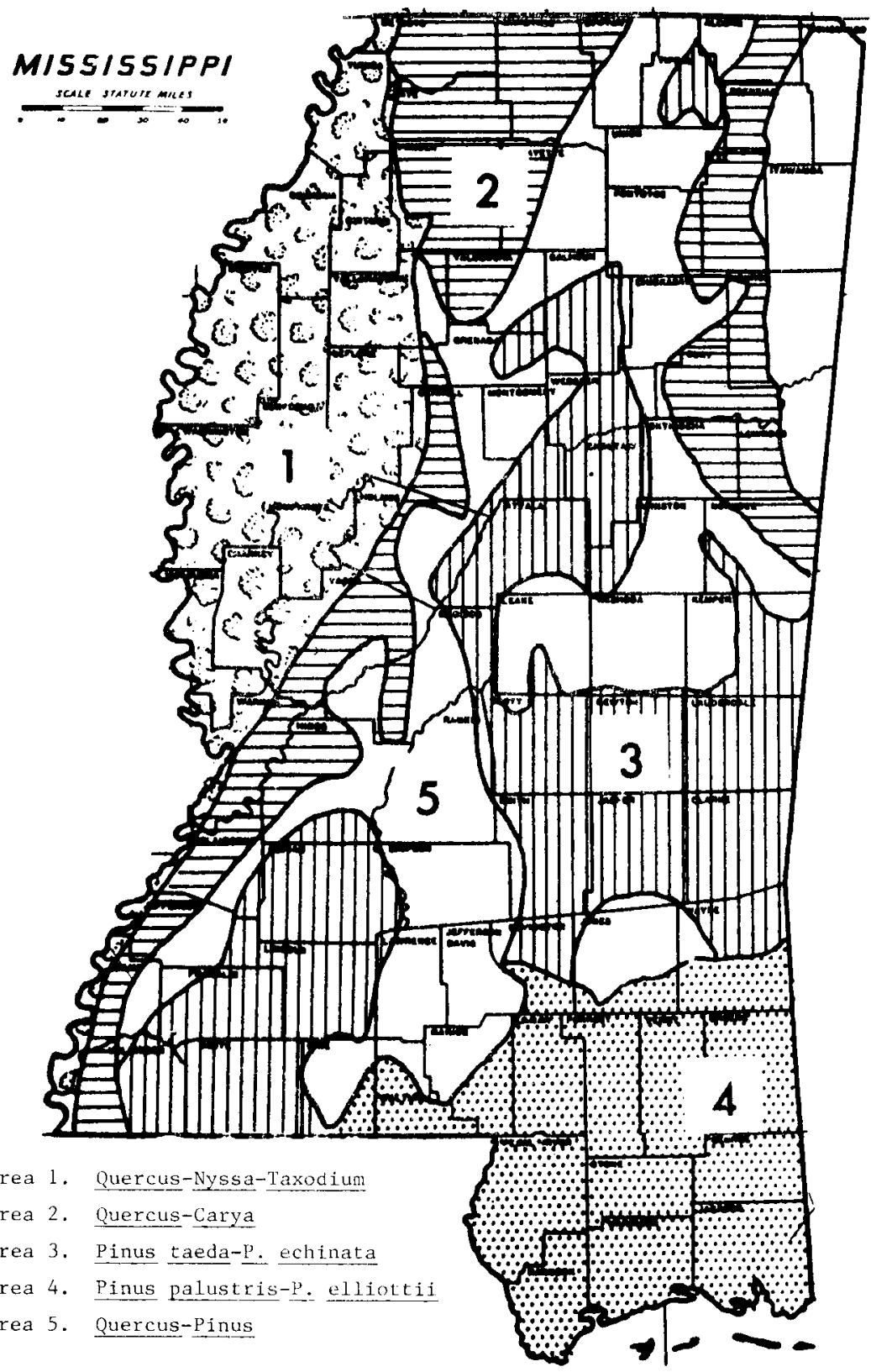

FIG. 1. - Beekeeping areas of Mississippi (U.S.A.) based on vegetational areas (Brown, [1970?]). 


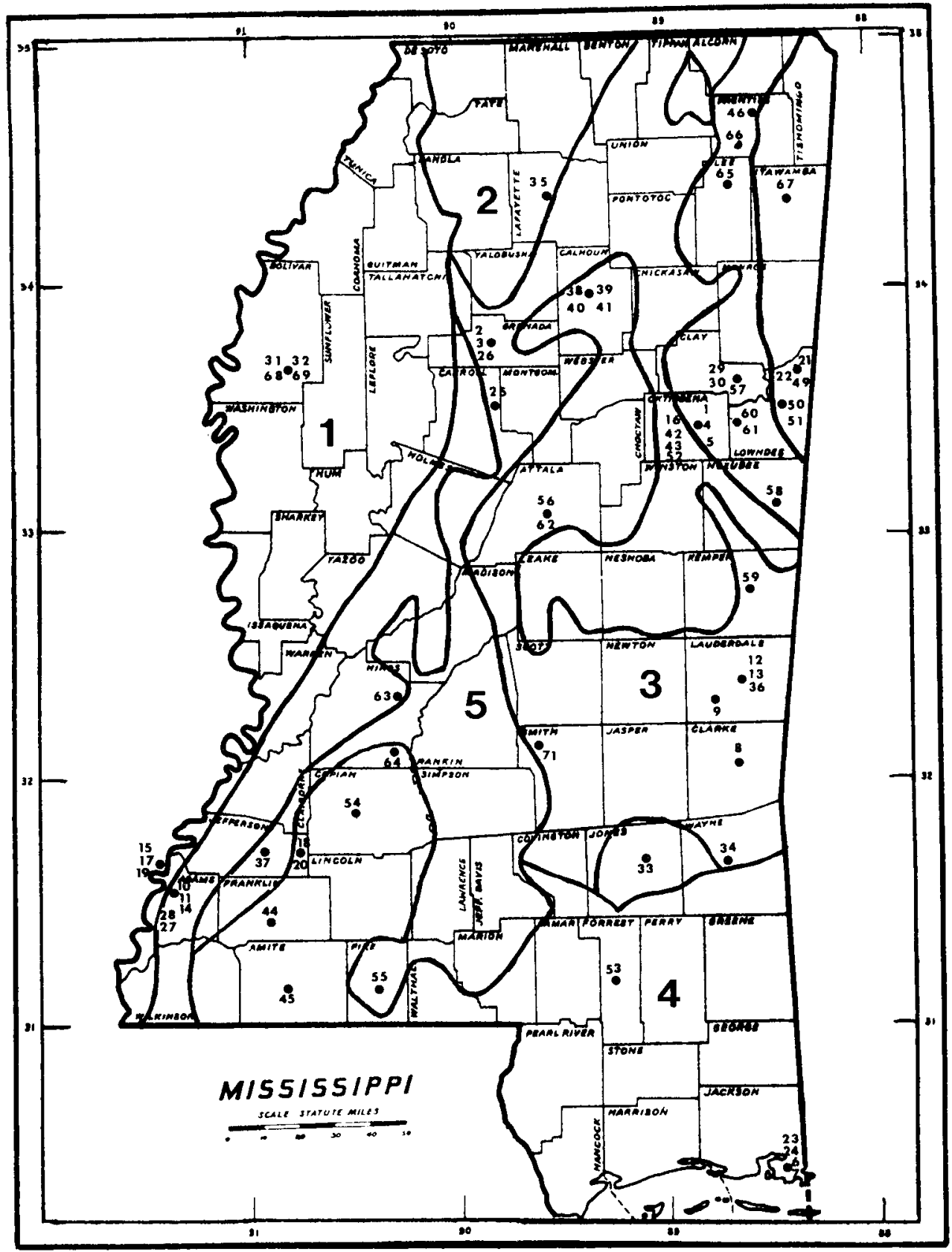

FIG. 2. - Sample sites. Bold lines define beekeeping areas of Figure 1. 


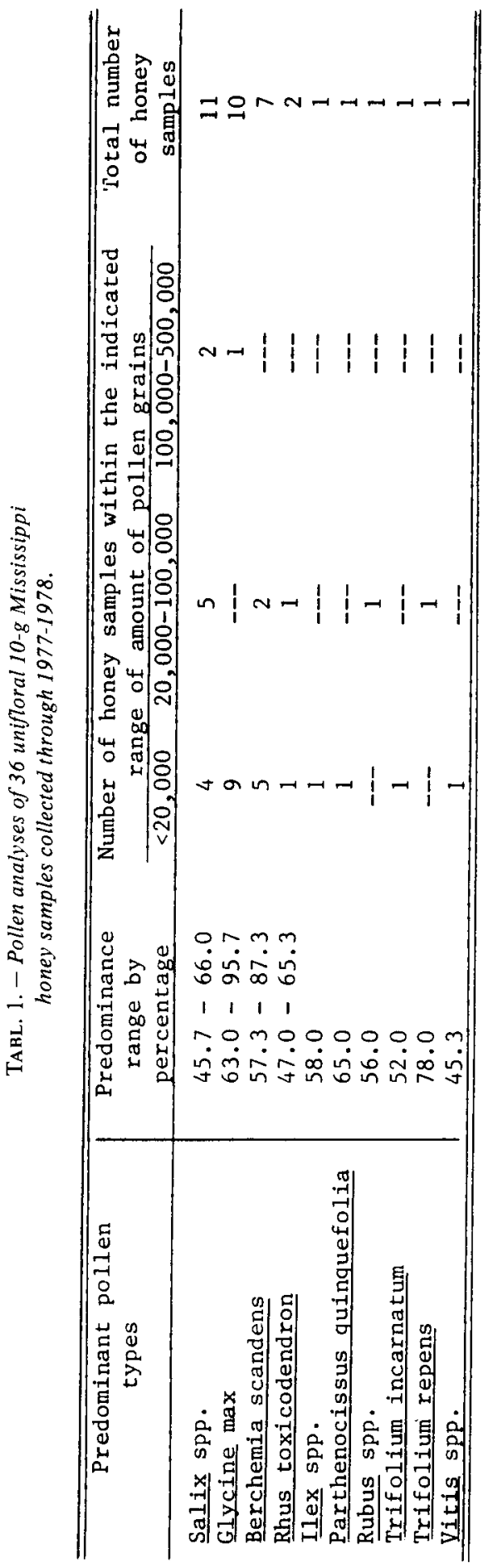


Percentage frequencies of occurrence for all 84 pollen types are shown in Figure 3. Although 84 types were identified, the actual number of species was greater because several types included more than one taxon (e.g., Rosaceae included Prunus spp., Pyrus spp., etc.). Twelve pollen types appeared in $50 \%$ or more of the honey samples. They were in order of decreasing percentage frequency of occurrence $R u b u s$ spp.; Salix spp.; Rhus toxicodendron; Trifolium repens; Berchemia scandens; Gramineae (Poaceae), Grass Family; Nyssa sylvatica Marsh., black-gum or black tupelo; Rosaceae, Rose Family; Quercus spp., oak; Trifolium incarnatum L., crimson clover; Vitis spp., wild grape; and Cornus spp., dogwood. Seventeen pollen types occurred in $20-49 \%$ of the samples; 12 types, $10-19 \%$ of the samples.

The number of different pollen types per honey sample based on all the pollen types identified in the honey samples is shown in Figure 4. Area 1 honey samples averaged 16.6 pollen types per sample; Area 2, 19.1 types; Area 3, 19.0 types; Area 4, 21.6 types; Area 5, 20.5 types. The 68 Mississippi honey samples averaged 19.1 pollen types per sample and 15.9 nectariferous pollen types. The number of different pollen types per honey sample based only on the pollen grains of nectariferous species is presented in Figure 5.

\section{DISCUSSION}

\section{Botanical origin}

The leading botanical sources of commercial Mississippi honeys based on the total number of their pollen grains occurring in the samples were Salix spp. (mostly $S$. nigra Marsh., black willow), Berchemia scandens and Glycine max; Rubus spp., Rhus toxicodendron and Trifolium repens were less significant. Based on percentage frequency of occurrence (Fig. 3), Salix spp., Rubus spp. and $R$. toxicodendron exhibited a range of $92.6-94.1 \%$; $B$. scandens and $T$. repens, 79.4-80.9\%; G. max, $44.1 \%$. Salix spp., $G$. $\max$ and $B$. scandens produced the greatest number of unifloral honeys. Important nectar contributors in isolated samples (Table 3) were Trifolium incarnatum; Vitis spp.; Parthenocissus quinquefolia (L.) Planch., Virginia creeper; long-spined Compositae (Asteraceae), Sunflower Family; Rhus copallina L., dwarf sumac; Vicia spp., vetch; Ilex spp., holly; Zanthoxylum clava-herculis L., Herculesclub, toothache tree; and Cyrillaceae [Cliftonia monophylla (Lam.) Sarg., black titi and Cyrilla racemiflora L., titi]. Nyssa sylvatica and miscellaneous Rosaceae (except Rubus spp.) exhibited a high frequency of occurrence (Fig. 3). Photographs of many pollen grains discussed here were previously published (LiEux, 1972, 1975, 1977, 1978). 


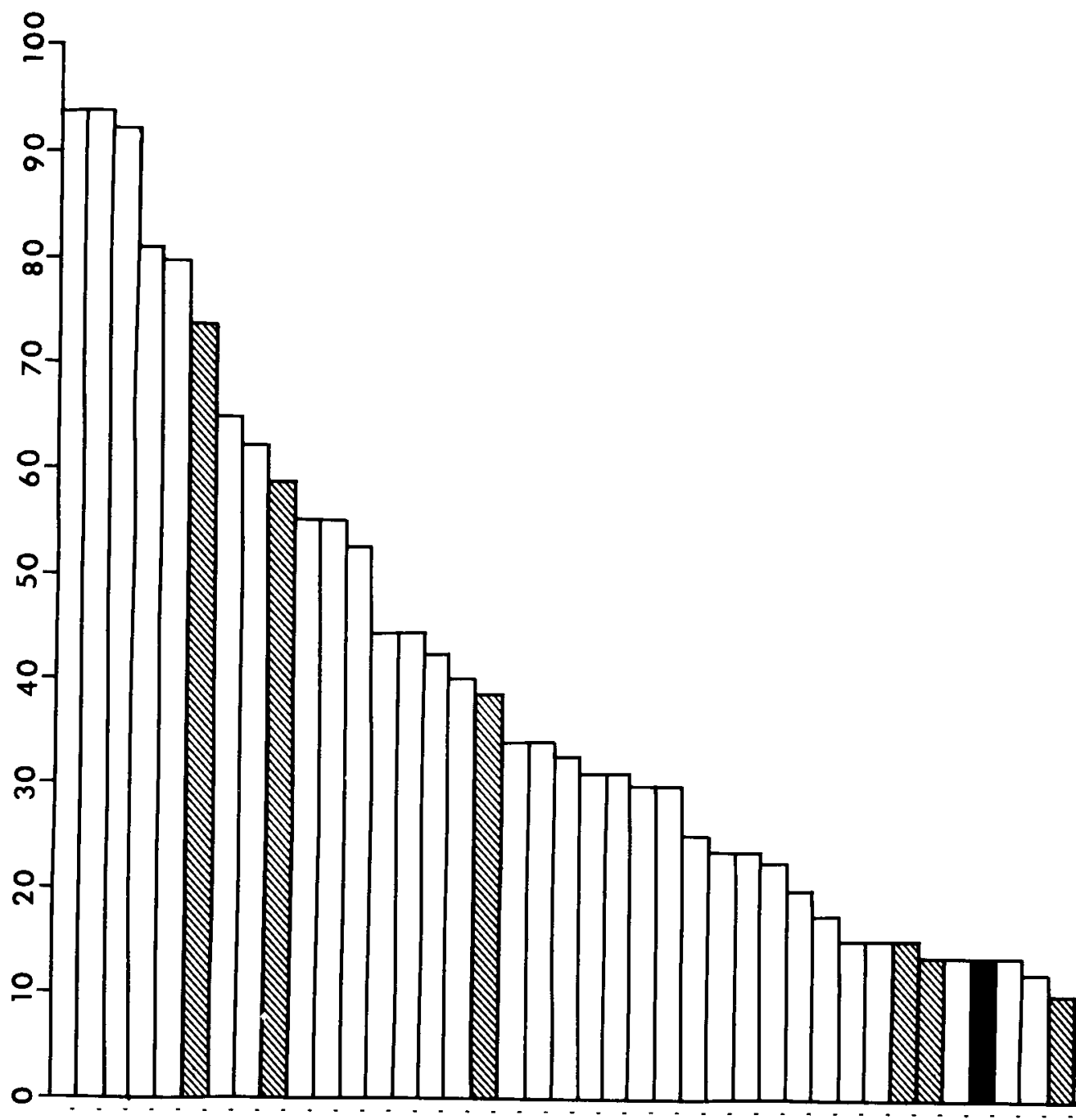


FIG. 3. - Percentage frequency of occurrence of 84 pollen types in 68 Mississippi honey samples.
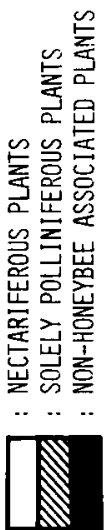


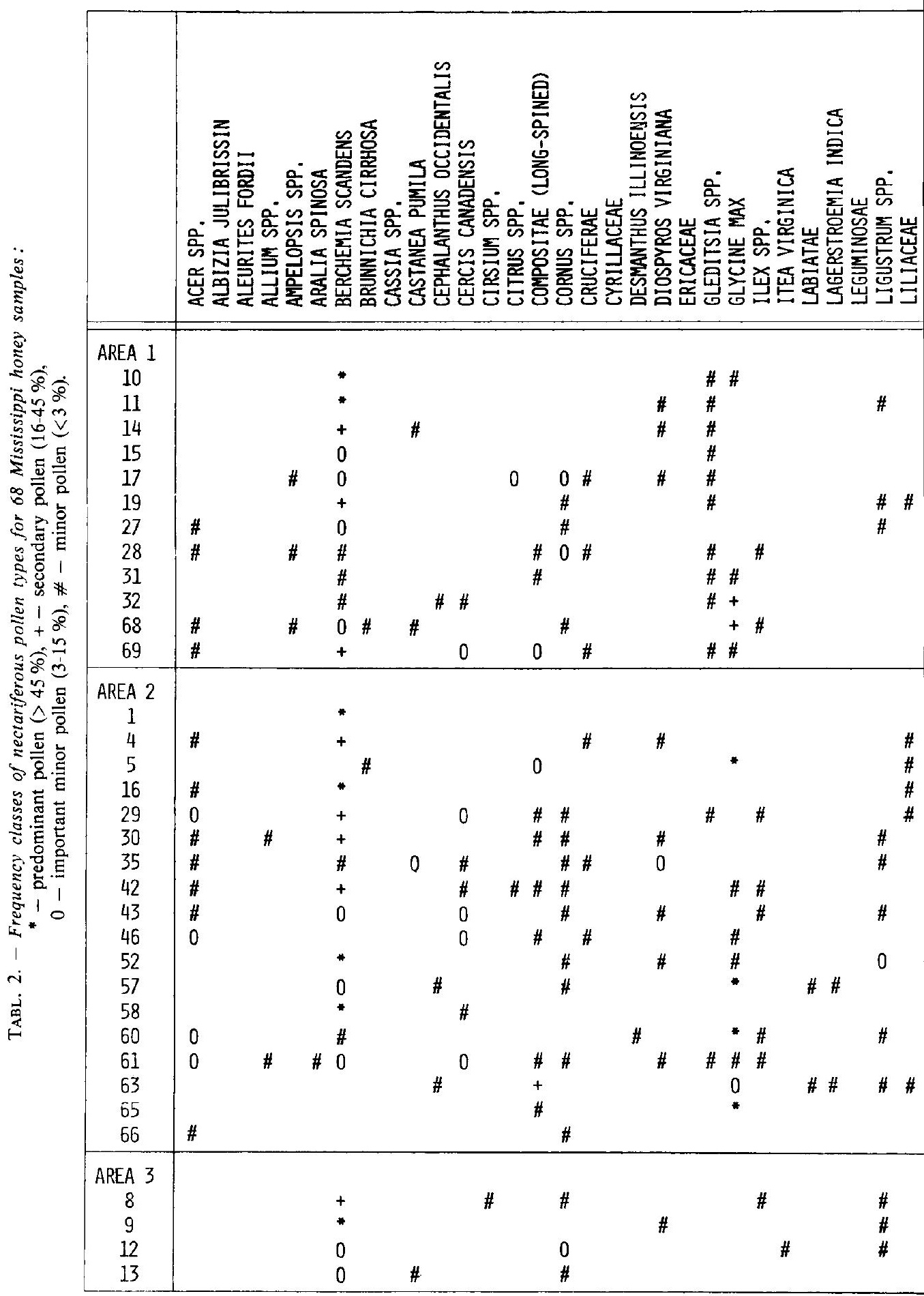




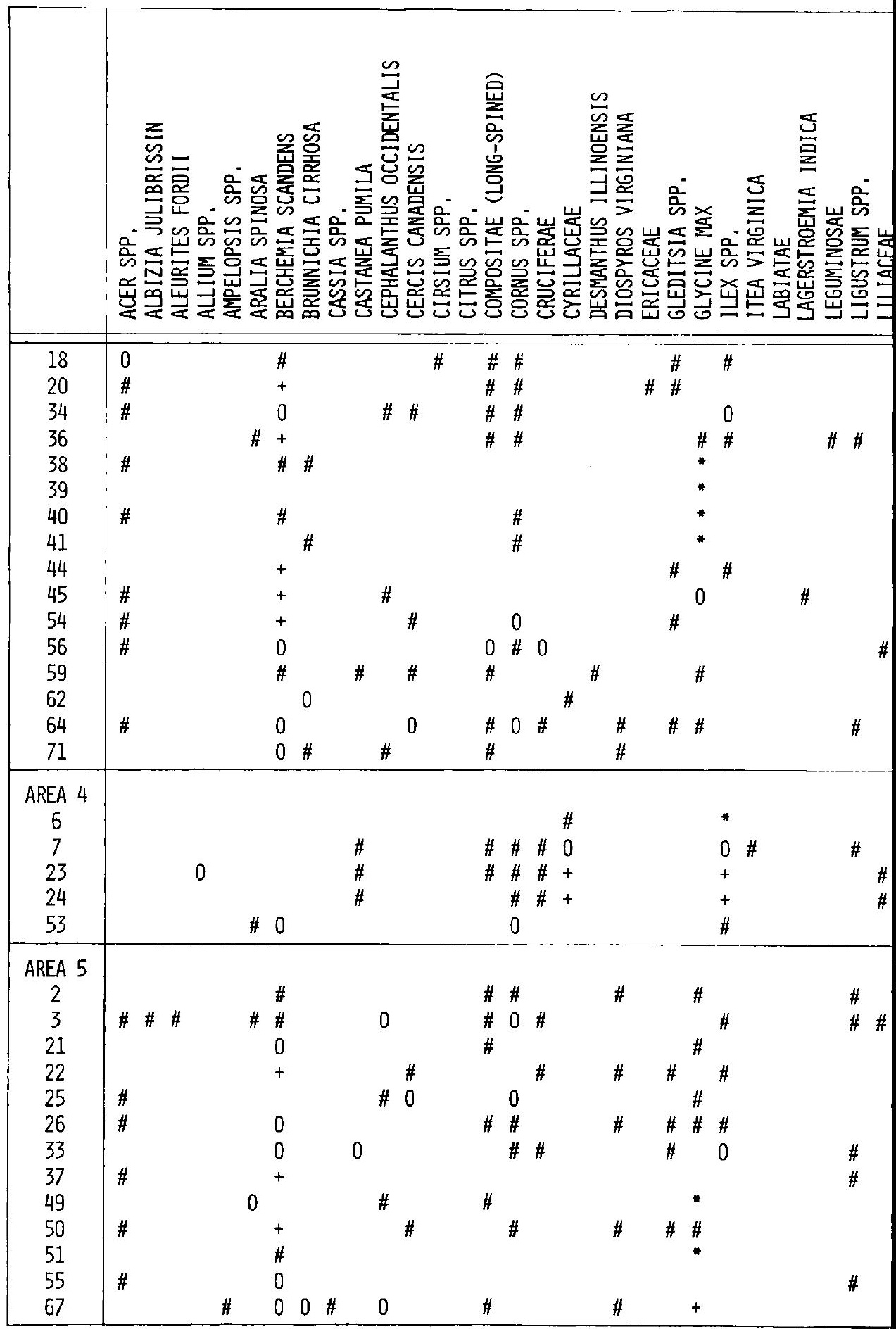




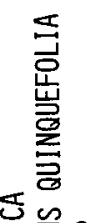

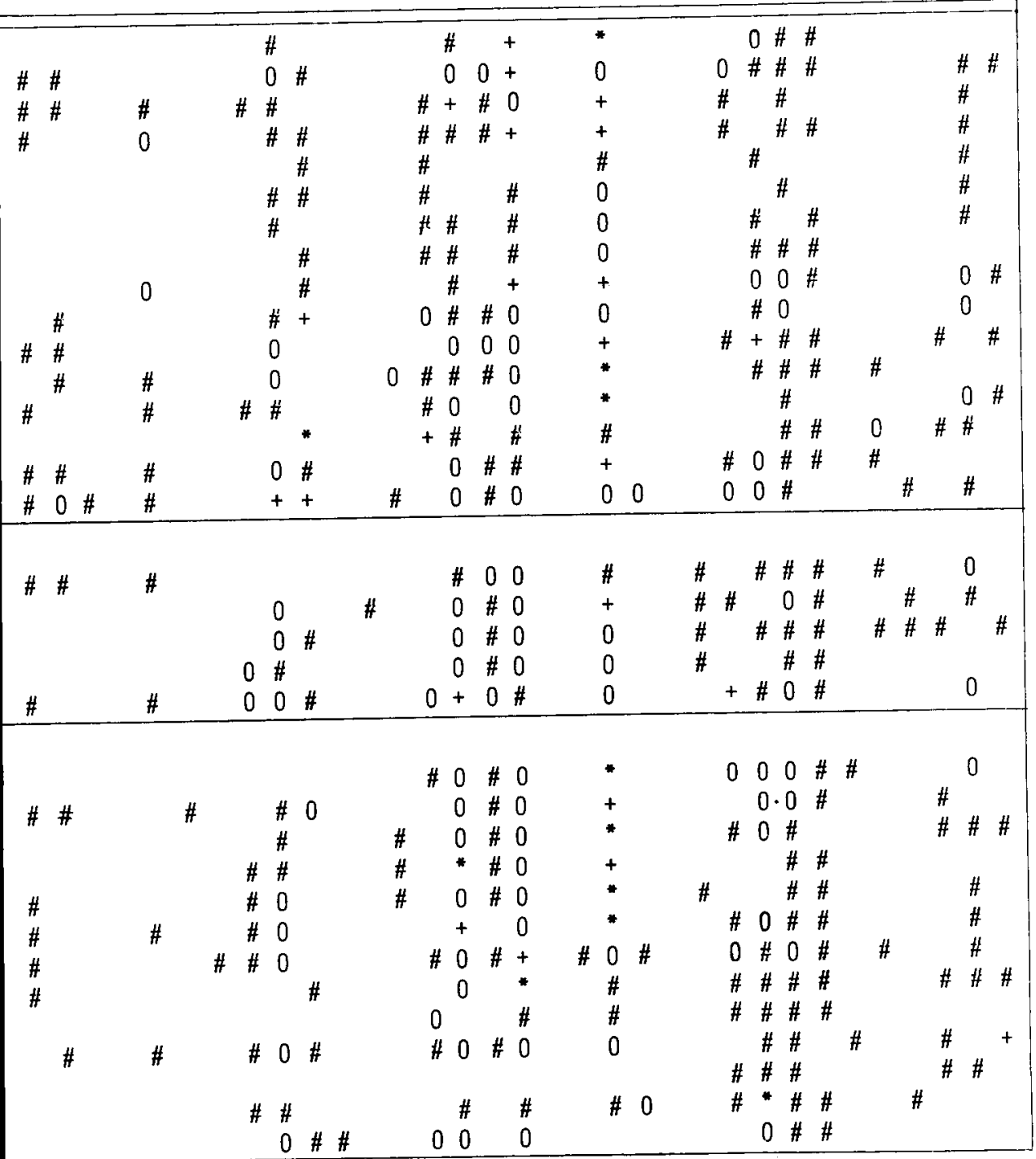




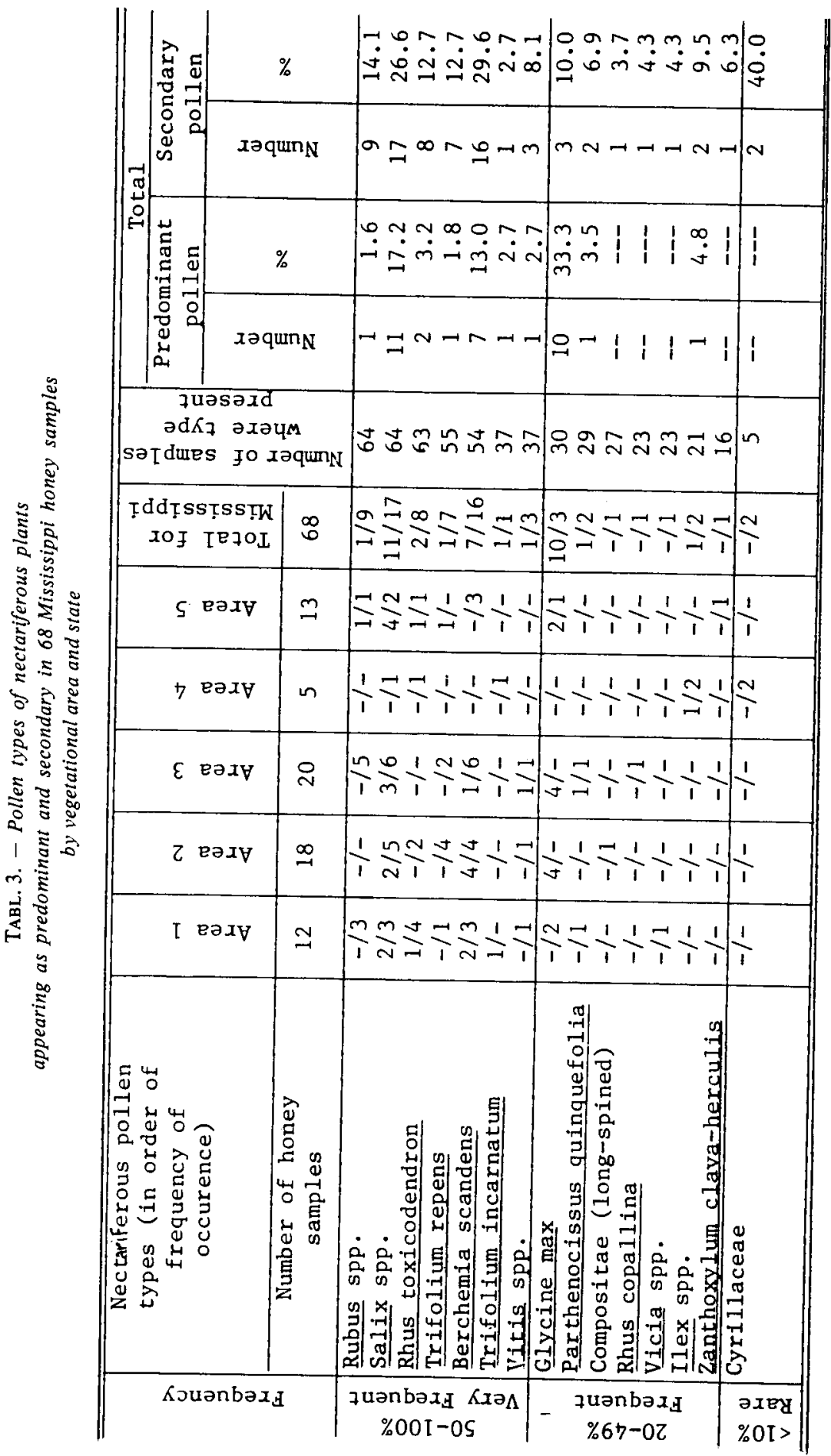




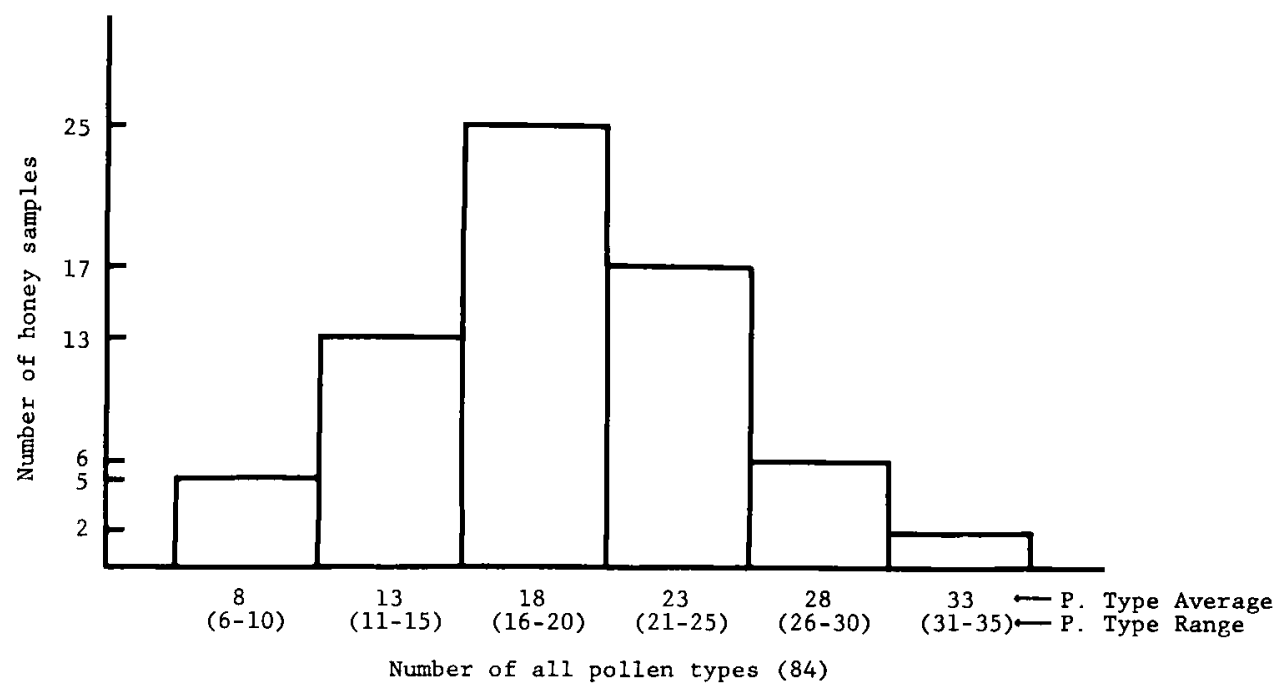

FIG. 4. - Range of different pollen types within honey samples.

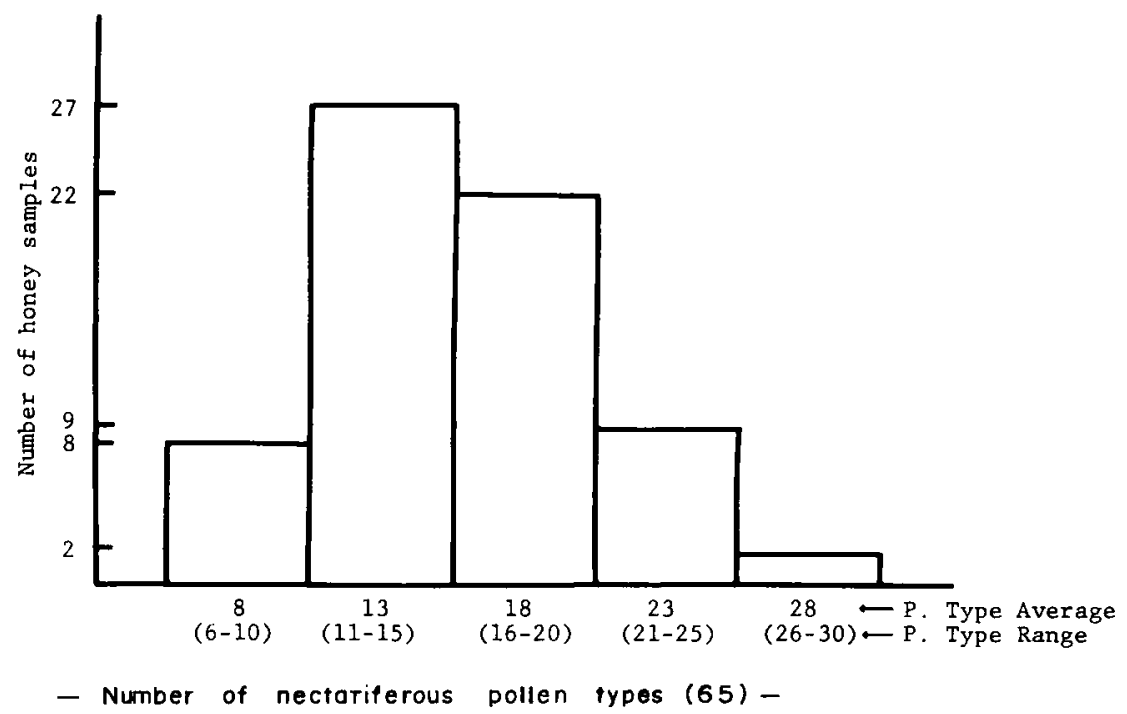

FIG. 5. - Range of different nectariferous pollen types within honey samples.

Salix-type grains occurred in all honey samples except four from northeastern Mississippi. This pollen type was predominant in 11 samples, secondary in 17, ranged from a dominance of $66 \%$ to less than $3 \%$ and averaged 53 grains per 300 grains in the 68 samples. However, because willow is dioecious, the pollen counts may be deceptively low, when using pollen grains as an index of the nectar contribution of a plant. Conversely, willow's production of relatively great quantities of pollen 
(FAEGRI and IvERSEN, 1975) and small pollen grains (LiEUX, 1975) could offset the affect of dioecism. Demianowicz (1964) reported an apparent inverse relationship between pollen grain size and number in honey. Salix unifloral samples were generally richer in pollen than were unifloral samples of Glycine max and Berchemia scandens, both of which had grains larger than those of Salix spp. Maurizio (1958) found that three of five Salix unifloral samples had 20,000-100,000 grains; two had over 100,000 grains. Salix was reported as a major Louisiana honey plant (LIEUX, 1972), present in eight of 11 Florida honeys (VoRwoHL, 1970) and a valuable honey plant in the Gulf States and California (PeLletT, 1947).

Berchemia scandens pollen grains were identified in 54 of 68 honey samples, predominant in seven samples and secondary in 16. They had a dominance of $87.3 \%$ to less than $3 \%$ and averaged 50 grains per 300 grains in the honey samples. Rattan vine was reported as a major honey plant in Louisiana (LIEUX, 1972) and other sections of the southern United States (Pelletr, 1947). It was not identified for Florida (VoRwOHL, 1970).

Glycine max grains were found in 29 of 68 samples, predominant in 10 samples and secondary in three. They showed a dominance ranging from $96 \%$ to less than $3 \%$ and averaged 44 grains per 300 grains in the honey samples. Unifloral samples of soybean showed greater dominance by a single pollen type than did any other unifloral honey. This trend was expected where apiaries were located adjacent to soybean fields. Glycine max was not listed by OERTEL (1939); soybeans were not widely planted in Mississippi in 1939 (Mississippi Crop and Livestock Reporting Service, 1955). In 1977, however, 3,750,000 acres were planted in soybeans (Mississippi Crop and Livestock Reporting Service, 1977). Soybean, occasionally important in Louisiana (LIEUX, 1972), was not identified in Florida samples (VoRWOHL, 1970).

Rubus spp. pollen grains were present in 64 of 68 samples, predominant in one and secondary in nine. Rubus spp. grains had a dominance of $56 \%$ to less than $3 \%$ and averaged 27 grains per 300 grains in the samples. Although Rubus spp. was not a major honey source in Mississippi, it was in Louisiana (Lieux, 1972). PelletT (1947) reported that blackberry and dewberry were good honey sources.

Rhus toxicodendron grains were present in 63 of 68 samples, predominant in two and secondary in eight. The grains averaged 24 per 300 in the samples. Poison ivy was not reported by OERTEL (1939), probably because commercial beekeepers were reluctant to admit that poison ivy was significant among the nectar-secreting flora (LiEUX, 1972). Most species of Rhus attract bees, although bees produce surplus Rhus honey only in limited localities (Pellett, 1947).

Trifolium repens pollen grains were present in 55 samples, predominant in one and secondary in seven. However, when white clover appeared as the predominant form, there was a relatively high percentage ( $7.3 \%$ ) of Citrus sp. grains and a very low 
total pollen grain count. Louveaux et al. (1978) reported Citrus pollen grains as under-represented in honey and defined $10-20 \%$ as indicating unifloral Citrus honey. In Louisiana, unlike in Mississippi, T. repens appeared as a major honey source (LIEUX, 1972).

Important nectariferous plants not listed by OeRTel (1939) were Trifolium incarnatum, Parthenocissus quinquefolia, Rhus copallina, Vicia spp. and Zanthoxylum clava-herculis (same as UK-11 in LiEUX, 1972). Other nectariferous plants not listed by OeRTEL (1939), but present in at least one sample as an important minor pollen type, were Cornus spp.; Magnolia spp.; Lonicera spp., honeysuckle; Cruciferae (Brassicaceae), Mustard Family; Verbena spp., vervain; Castanea pumila (L.) Mill., chinquapin; Aralia spinosa L., Hercules'-club, Devil's-walking stick; Sapium sebiferum (L.) Roxb., Chinese tallow tree; Allium spp., onion or garlic; Citrus spp.; and Saururus cernuus L., lizard's tail. Those species present only as a minor pollen type were Liliaceae, Lily Family; Ranunculus spp., buttercup; Symplocos tinctoria (L.) L'Her., horse-sugar; Umbelliferae (Apiaceae), Parsley Family; Viburnum spp.; Cirsium spp., thistle; Desmanthus illinoensis (Michx.) MacM.; Itea virginica L., Virginia willow; Lagerstroemia indica L., crape-myrtle; Albizia julibrissin Durazz., mimosa-tree; Aleurites fordii Hemsl., tung-oil tree; Ericaceae, Heath Family; Ludwigia spp., waterprimrose; Lythrum spp., loosestrife; Sabal minor (Jacq.) Pers., palmetto; and Sagittaria spp., arrowhead.

Pollen grains of plants that are anemophilous and visited by bees for pollen, but not nectar, such as Gramineae; Quercus spp.; and Fraxinus spp., ash; and the pollen grains of plants that are anemophilous and non-honeybee-associated such as Chenopodiaceae, Goosefoot Family and Plantago spp., plantain, (PELleTt, 1947) were assumed accidental contaminants in the honey and were not included in the 300 grain counts. Certain anemophilous species [Celtis laevigata Willd., hackberry; Ulmus spp., elm; Myrica spp., wax myrtle; and Planera aquatica (Walt.) J. F. Gmel., waterelm], previously associated with honey production (PELLETT, 1947), were also not counted.

Honeybee-associated plants listed by OeRTel (1939), but not identified in this study, were Tilia spp., basswood; Medicago lupulina L., black medic; Robinia sp. (probably refers to $R$. pseudo-acacia L.), black locust; Trifolium pratense L., red clover; Melilotus spp., sweet clover; Rhamnus lanceolata Pursh., buckthorn; Gossypium sp., cotton; Hibiscus moscheutos L., swamp rose-mallow; Richardia scabra L., Mexican-clover; and Rhus glabra L., smooth sumac.

Most of the 68 honeys had less than 20,000 grains per 10-g sample, but LOUvEAUX et al. (1978) reported the absolute number of plant constituents generally below 20,000 only in unifloral honeys poor in pollen grains (e.g. Citrus). The unifloral honeys of Mississippi are not types known to be poor in pollen grains, except possibly one sample of Parthenocissus quinquefolia and one of Trifolium incarnatum. Both of these species have large grains and an apparent inverse 
relationship exists between the size and number of pollen grains in honey. The remaining honeys from Mississippi appeared as mixed floral honeys with little input from honeydew. Both groups, according to Louveaux et al. (1978), should be in the $20,000-100,000$ range.

LOUVEAUX et al. (1978) placed floral honeys rich in pollen and honeydew in an absolute number category of 100,000 to 500,000 . In this group for Mississippi, there were three unifloral honeys and two mixed floral honeys. One sample of unifloral Glycine max honey probably had a high total grain count due to pollen contamination during extraction since nine other $G$. max unifloral samples had less than 20,000 grains per 10-g sample.

Factors which likely contributed to the low total grain counts found in Mississippi honeys included increased mechanical loss of sediment from two additional decanting steps required by acetolysis, more refined beekeeping techniques and more efficient and cleaner extracting methods, and comparison of counts of only pollen grains to counts of absolute number of plant constituents.

Although most honey samples were of spring origin, 13 had more than $50 \%$ of their grains from summer or fall species (ten, unifloral Glycine max; one, unifloral Parthenocissus quinquefolia; two, large percentages of both); six, at least $16 \%$. Other summer and fall species included Sapium sebiferum, Cephalanthus occidentalis L. (buttonbush), Saururus cernuus, Rhus copallina and Verbena spp.

\section{Geographical origin}

Honeys from the different beekeeping areas of Mississippi (Fig. 1 and 2) could not be clearly differentiated from each other either by diversity of pollen types or characteristic pollen types. Area 1 was a floodplain distinguished by soybean and cotton fields. Remaining swamps were dominated by Taxodium distichum (L.) Rich., cypress and Nyssa aquatica L., tupelo gum. The better drained sites were dominated by several species of Quercus, Salix nigra, etc. Honey samples from this area were characterized by Berchemia scandens, Salix spp. and Rhus toxicodendron pollen grains. Trifolium repens, Rubus spp. and Gleditsia spp. grains occurred in most samples. Honey samples were obtained mostly from the southern portion of the area where soybean acreage was relatively low. In the northern part of Area 1, insecticides were presumably applied to cotton and beekeeping was curtailed.

Area 2 consisted of a western part fringing the floodplain and an eastern part where most of the honey samples were obtained. This area was mainly hilly and characterized by upland species of Quercus and Carya. The honey samples were mostly influenced by Berchemia scandens, Glycine max and Salix spp. Pollen grains of Rhus toxicodendron and Trifolium repens occurred in all the samples; Rubus spp. grains, in all but one. Soybean acreage was high and cotton acreage relatively low (Mississippi Crop and Livestock Reporting Service, 1977) where soybean honey production occurred. 
Area 3 included the drier and more sandy soils of southwestern Mississippi and was dominated by pines with some upland hardwoods such as Nyssa sylvatica. The most important nectar-producing species were Salix spp., Glycine max and Berchemia scandens. Glycine max pollen grains, however, were absent from over half of the samples. Vitis spp., Rubus spp., Rhus toxicodendron and Nyssa sylvatica were important pollen contributors in isolated samples and/or showed a high frequency of occurrence.

Area 4 was mostly naturally vegetated with Pinus spp. Pollen types occurring in all five samples of this area were Ilex spp., Rhus toxicodendron, Rosaceae, Rubus spp. and Salix spp. Other notable species were Cornus spp., Cyrillaceae, Nyssa sylvatica and Symplocos tinctoria. No samples from Area 4, where soybean production was comparatively low, contained soybean pollen.

The natural vegetation of Area 5 was mostly dominated by oak and pine species. Salix spp., Glycine max, Rubus spp., Rhus toxicodendron and Trifolium repens appeared to be the most influential nectar producers; Berchemia scandens and Nyssa sylvatica were less significant.

The higher species diversity and lower unifloral production of Mississippi honeys compared to Quebec honeys (FelleR-DEMALSY and LAMONTAGNE, 1979) correlated with the increased species diversity characteristic of a more temperate zone. Species diversity in Mississippi was determined on all pollen types present in the samples as apparently was the case in Quebec.

\section{ACKNOWLEDGEMENTS}

The present investigation was partly supported by a Louisiana State University Council-on-Research Summer Faculty Grant. Dr. Mary G. CURRY is thanked for critically reading the manuscript.

Received for publication in December 1980.

\section{RÉSUMÉ}

\section{ANALYSE DU MIEL DU MISSISSIPPI (U.S.A.) :}

POLLEN, COULEUR ET TENEUR EN EAU

On a appliqué à 68 échantillons de miel récoltés en 1977 et 1978 dans le Mississipi (États-Unis) (Fig. 1 et 2) une technique d'analyse utilisant l'acétolyse. Le nombre total de grains de pollen par échantillon de $10 \mathrm{~g}$, le spectre pollinique, la couleur et la teneur en eau des miels ont été déterminés. On a supposé une corrélation directe entre la teneur en pollen d'une plante donnée et la contribution du nectar de cette plante au miel.

Le nombre total de grains et le spectre pollinique sont basés sur le dénombrement, par échantillon, de 300 grains de pollen provenant de plantes nectarifères potentielles. On a dénombré séparément les pollens associés et l'identification a été poussée jusqu'au taxon le plus fin possible. La couleur de chaque miel a été 
déterminée à l'aide d'un colorimètre simple (Phoenix Precision Instrument Co.), la teneur en eau à l'aide d'un réfractomètre à main Bausch et Lomb.

Dans l'état du Mississippi 67,6\% des échantillons de miel ont moins de 20000 grains par $10 \mathrm{~g} ; 25,0 \%$ de 20000 à $100000 ; 7,4 \%$ de 100000 à 500000 . Les dénombrements concernant uniquement les miels monofloraux sont présentés dans le tableau 1. Sur les 84 types de pollens identifiés (Fig. 3), 65 proviennent de plantes nectarifères, 11 de plantes pollinifères et 8 de plantes sans rapport avec les abeilles. Le tableau 2 fournit un spectre pollinique complet pour les 65 espèces nectarifères.

Les principales sources botaniques des miels commerciaux du Mississipi sont, d'après le nombre total de grains de pollen présents dans les échantillons : Salix spp. (surtout S. nigra), Berchemia scandens et Glycine max; Rubus spp., Rhus toxicodendron et Trifolium repens sont moins significatifs. D'après la f.équence du pourcentage de présence (i.e. le nombre d'échantillons de miel dans lesquels un type de pollen est présent), les espèces dominantes sont par ordre décroissant d'importance (Fig. 3) : Rubus spp., Salix spp., $R$. toxicodendron, $T$. repens et $B$. scandens. Salix spp., $G$. max et $B$. scandens produisent le plus grand nombre d'échantillons monofloraux. Dans les échantillons isolés Trifolium incarnatum, Parthenocissus quinquefolia, des Composées à longues épines (Asteraceae), Rhus copallina, Vicia spp., Ilex spp., Zanthoxyllum clava-herculis et des Cyrillaceae (Cliftonia monophylla et Cyrilla racemiflora) sont des producteurs de nectar importants.

$52,9 \%$ des échantillons sont d'origine monoflorale; les autres sont des miels toutes fleurs; $61,7 \%$ renferment de 16 à 25 types de pollen (Fig. 4). La plupart des échantillons sont produits en été (G. max) ou au printemps. Les types de pollen, autres que $G$. max, qui indiquent des miels d'été ou d'automne, comprennent $P$. quinquefolia, Sapium sebiferum, Cephalanthus occidentalis, Saururus cernuus, $R$. copallina et Verbena spp. L'analyse pollinique n'a pas permis de distinguer clairement les miels provenant des différentes régions apicoles.

Une analyse discriminante a montré que la variation inter-groupes ne permettait pas d'utiliser une analyse de variance pour comparer le nombre total de grains de pollen et la couleur ou la teneur en eau avec le type floral.

\section{ZUSAMMENFASSUNG}

EINE ANALYSE VON MISSISSIPPI-HONIGEN (U.S.A.) : POLLEN, FARBE UND WASSERGEHALT

An 68 kommerziellen Honigproben, die in den Jahren 1977 und 1978 am Mississippi, U.S.A., gesammelt worden waren (Abb. 1 und 2), wurde unter Anwendung der Technik der Azetolyse eine Honiganalyse durchgeführt. Es wurden die Gesamtzahl der Pollenkörner in einer $10 \mathrm{~g}$-Probe, das Pollenspektrum, die Farbe und der Wassergehalt bestimmt. Es wurde angenommen, dass zwischen dem Pollenanteil einer bestimmten Pflanzenart im Honig und ihrem Beitrag zum Nektar ein direkter Zusammenhang besteht.

Die Gesamtpollenzahl und das Pollenspektrum wurden durch die Auszählung von 300 Pollenkörnern von potentiell nektarliefernden Pflanzen bestimmt. Andere im Honig vorhandene Pollenkörner wurden getrennt gezählt. Die Körner wurden auf der tiefstmöglichen taxonomischen Einheit (Gattung oder Art) bestimmt. Die Farbe wurde mittels einer einfachen Farbskala klassifiziert (Phœnix Precision Instrument Co.); der Wassergehalt wurde mit einem Handrefraktometer von Bausch und Lomb gemessen.

In Mississippi hatten 67,6\% der Honigproben weniger als $20000 \mathrm{Körner}$ in der 10 g-Probe; $25 \%$ hatten zwischen 20000 und $100000 ; 7,4 \%$ zwischen 100000 und 500 000. Die Zählungen von EinsortenHonigen sind in Tabelie 1 zusammengestellt. Von den 84 Pollentypen, die bestimmt wurden, stammen 65 von Nektarpflanzen; 11 von Pollenpflanzen; 8 Typen stammen von Pflanzen, die nicht von Honigbienen besucht werden. Tab. 2 gibt ein vollständiges Pollenspektrum für die 65 Nektarpflanzen.

Die führenden Pflanzenarten in den kommerziellen Mississippi-Honigen waren nach der Gesamtzahl der Pollenkörner in den Proben Salix spp. -meist S. nigra), Berchemia scandens und Glycine max; Rubus 
spp., Rhus toxicodendron und Trifolium repens waren von geringerer Bedeutung. Ausgehend von der prozentuellen Häufigkeit des Vorkommens (dh. von der Häufigkeit der Honigproben, in denen ein Typ vorkam) waren folgende Arten führend (in fallender Reihenfolge; Abb. 3) : Rubus spp., Salix spp., $R$. toxicodendron, T. repens und B. scandens. Salix spp., G. max und B. scandens erzeugten die grösste Zahl von Sortenhonigen. Wichtige Nektarlieferanten in einzelnen Proben waren (Tab. 3) Trifolium incarnatum, Parthenocissus quinquefolia, langstachelige Compositen (Asteraceae), Rhus copallina, Vicia spp., Ilex spp., Zanthoxylum clava-herculis und Cyrillaceae (Cliftonia monophylla und Cyrilla racemiflora).

Von den Proben waren 52,9\% Einsortenhonige; die übrigen Proben stammten von einer gemischten Tracht; $61,7 \%$ enthielten 16-25 verschiedene Pollentypen (Abb. 4). Die meisten Proben stammten aus der Sommertracht (G. max) oder von Frühjahrsblüten. Pollentypen, die ausser G. max Sommer- oder Herbsttrachten anzeigten, waren $P$. quinquefolia, Sapium sebiferum, Cephalanthus occidentalis, Saururus cernuus, Rhus copallina und Verbena spp. Honige aus verschiedenen Bienenzuchtgebieten waren durch die Pollenanalyse nicht klar zu unterscheiden.

Eine Diskriminanzanalyse zeigte, dass die Variation innerhalb der Gruppe die Anwendung einer Varianzanalyse für den Vergleich der gesamten Pollenzahl und der Farbe oder dem Wassergehalt mit der psflanzlichen Herkunft der Honige nicht gestattete.

\section{LITERATURE CITED}

Brown C. A., 1960. - Palynological techniques. C. A. Brown, Louisiana State Univ., Baton Rouge, $188 \mathrm{p}$.

Brown C. A., [1970?]. - Mississippi trees. Mississippi Forest. Comm. Pub. 7, 90 p.

Correll D. S. and Johnston M. C., 1970. - Manual of the vascular plants of Texas. Texas Res. Found., Renner, $1881 \mathrm{p}$.

Demianowicz Z., 1964. - Characteristik der Einartenhonige. Ann. Abeille, 7, 273-288.

ERdTMAN G., 1952. - Pollen morphology and plant taxonomy, angiosperms (An introduction to palynology. I). The Chronica Botanica Co., Waltham, Mass. $539 \mathrm{p}$.

FAEgri K. and IverSeN J., 1975. - Textbook of pollen analysis, 3rd ed. Hafner Press, New York, $295 \mathrm{p}$.

Feller-Demalsy M. J. and Lamontagne Y., 1979. - Pollen analysis of honeys from Québec (in French, English summary). Apidologie, 10, 313-340.

HofFMAN C. A., 1930. - The morphology of the pollen grains of some honey plants. Pages 967-990 in L. H. Pammel and C. M. King, eds. Honey plants of Iowa. Iowa Geol. Surv. Bull. 7.

LIEUX M. H., 1972. - A melissopalynological study of 54 Louisiana (U.S.A.) honeys. Rev. Palaeobot. Palynol., 13, 95-124.

LIEUX M. H., 1975. - Dominant pollen types recovered from commercial Louisiana honeys. Econ. Bot., 29, 87-96.

LIEUX M. H., 1977. - Secondary pollen types characteristic of Louisiana honeys. Econ. Bot., 31, 111-119.

LiEUX M. H., 1978. - Minor honeybee plants of Louisiana indicated by pollen analysis. Econ. Bot., 32, 418-432.

LieuX M. H., 1980. - Acetolysis applied to microscopical honey analysis. Grana, 19, 57-61.

Louveaux J., 1966. - Pollen analysis of some Canadian honeys (in German, English summary). Zeitschrift für Bienenforschung, 8, 195-202.

Louveaux J., Maurizio A. and Vorwohl G., 1978. - Methods of melissopalynology. Bee World, 59, 139-157.

Maurizı A., 1958. - Beiträge zur quantitativen Pollenanalyse des Honigs. Ann. Abeille, 1, 93-106. 
MaURizio A. and Louveaux J., 1963. - Commission internationale de Botanique apicole (U.I.S.B.). Méthodes d'analyse pollinique des miels. Ann. Abeille, 6, 75-76.

Mississippi Crop and Livestock Reporting Service, 1955. Base book of Mississippi agriculture, 1866-1953. Jackson, Ms., $176 \mathrm{p}$.

Mississippi Crop and Livestock Reporting Service,'1977. Mississippi agricultural statistics, 1973-1976. Jackson, Ms. 52 p.

Oertel E., 1939. - Honey and pollen plants of the United States. U.S. Dep. Agr. Circ., 554, 64 p. PARKer R. L., 1923. - Some pollens gathered by bees. Amer. Bee J., 63, 16-19.

Pellett F. C., 1947. - American honey plants, 4th ed. Orange Judd Pub. Co., Inc., New York, 467 p. SeChrist E. L., 1925. - The color grading of honey. U. S. Dep. Agr. Circ., 364, 7 p.

Todd F. E. and G. H. VANSELl, 1942. - Pollen grains in nectar and honey. J. Econ. Entomol., 728-731.

VoRwOHL G., 1970. - Microscopical spectrum of some Florida honeys (in German, English summary). Apidologie, 1, 233-269.

Young W. J., 1908. - A microscopical study of honey pollen. U. S. Dep. Agr. Bull. Chem., 110, 70-93.

YousE H. R., 1953. - A taxonomic study of sixty pollen grains collected by honey bees. Indiana Acad. Sci. Proc., 62, 114-121. 